\title{
Exploring a Community of Practice to Improve Quality of a Technology Integration Course in a Teacher Education Institution
}

\author{
Olgun Sadik \\ Indiana University, USA \\ Inonu University, Turkey \\ ORCID: 0000-0002-8852-8189
}

Received: 14 Aug 2020

Accepted: 14 Sep 2020

\begin{abstract}
This research was designed and conducted considering the theoretical and practical suggestions of designbased research (DBR) methodology and aimed to identify and address problems in a one-semester technology integration course at a Midwest university in the US. Community of practice (CoP) was used as the theoretical framework in this research to design and implement interventions, and improve the quality of the course. The researcher observed a community of teacher educators and aimed to make suggestions for building successful strategies for communities of practice in similar contexts. The study results showcased the connection between pedagogy, content and technology as an important theme for preparing future teachers in technology integration courses but also in all the teacher education courses. Furthermore, aligned with the previous literature, pre-service teachers' beliefs and confidence were identified as important conditions for effective technology integration. CoP was found as a challenging but helpful model when all the members share ideas in a supportive and balanced environment. An experienced member of the community acting as a moderator and facilitating the discussions was helpful to address the communication issues in a community of teacher educators.
\end{abstract}

Keywords: community of practice, design-based research, teacher education, technology integration

\section{INTRODUCTION}

Pre-service teacher education is the primary stage in teachers' preparation for effective technology integration in their classroom (Baturay, Gökçearslan, \& Ke, 2017; Tondeur, Van Braak, Ertmer, \& OttenbreitLeftwich, 2017). Preparing pre-service teachers for technology integration is a challenging task (Tondeur et al., 2012). In order to use technology effectively in their future classrooms, pre-service teachers need to develop technology, pedagogy and content knowledge (Harris, Mishra, \& Koehler, 2009). Furthermore, a large number of studies stressed positive beliefs and attitudes as prerequisites for effective technology integration (Ottenbreit-Leftwich, Glazewski, Newby, \& Ertmer, 2010; Sadaf, Newby, \& Ertmer, 2016; Tondeur, Van Braak, et al., 2017). In order to prepare pre-service teachers in the United States, most higher education institutions offer one standalone technology integration course (Elwood \& Savenye, 2015; Gronseth et al., 2010; Zipke, 2018). Giving one technology integration course in teacher education was found effective in increasing pre-service teachers' technology knowledge and skills (Chai, Koh, \& Tsai, 2010) and improving their value beliefs, self-efficacy and intentions to use technology in their future classrooms (Cullen \& Greene, 2011).

However, previous studies shared concerns regarding the content and quality of those courses (Sosa, 2009; Willis \& Cifuentes, 2005; Zipke, 2018). In order to address these concerns, in a review of over 100 teacher 
education programs in the United States, Ottenbreit-Leftwich, Glazewski, and Newby (2010) suggested that teacher education programs need to be constantly reviewed and revised on how they prepare pre-service teachers for effective technology integration. Otherwise, program requirements and practices would be short in any institutions with fast changes in society, education and technology. Considering the aforementioned concerns regarding success of technology integration courses and suggestions for constant reflection, evaluation and revision, the purpose of this study is to explore a community of teacher educators aimed to identify and address the areas for improvement in a technology integration course at a Midwest university. The participants were eight associate instructors (Al) and a professor teaching the technology integration course at a large teacher education institution.

The course content was same for multiple sections of the course but the instructors had different backgrounds, perspectives, and experience teaching it. In collaboration with the researcher, the instructors (the Als and the professor) aimed to improve the quality of the course and worked in a community of practice (COP). The challenge was how to get all the instructors with different backgrounds work together and have a class that not only helps the pre-service teachers achieve the learning goals but also one that works for the community. A scenario with a similar challenge can be seen in teacher education institutions using the one course format with multiple instructors teaching different sections of the course. Therefore, this study has potential outcomes and suggestions to improve teacher educators' practice while making suggestions for effective collaboration between them. The terms "teacher educators" and "instructors" are used interchangeably referring to the same group in this study.

\section{LITERATURE REVIEW}

Professional Learning Communities (PLN) and Communities of Practices (CoP) are common in K-12, where members of a community work in teams to plan and implement new content and strategies to improve their teaching, students' learning and organizational structure. PLNs are required practices in K-12 schools and teachers are asked to collaborate to address school or classroom issues (Dufour \& Eaker, 1998). School leadership asks teachers to collaborate to build collective capacity in their schools (Hord, 2004). However, building collective capacity depends on K-12 teachers' self-motivation, skills, and organizational culture (Stoll, Bolam, McMahon, Wallace, \& Thomas, 2006). Therefore, school administrators' need to support and monitor teachers' development in PLNs (Wang, 2016). On the other hand, CoPs are voluntary communities initiated as a result of personal or professional motivations in an organization (Brown \& Duguid, 1991; Wenger, McDermott, \& Snyder, 2002). Leadership between the community members can be formal or informal, and emerged from discussions in the group (Wenger, McDermott, \& Snyder, 2002).

CoPs are common in higher education and allow faculty to create innovative teaching practices, contribute to organizational development and improve their knowledge and skills (Jakovljevic \& Da Veiga, 2020). For example, in a study with 7000 faculty members of a Science, Tehnology, Enginerring and Math (STEM) community, Gehrke and Kezar (2017) stressed that engaging in a CoP contributed to departmental and organizational change. The community played important roles in the members' innovative actions. In another CoP study conducted at an Asian Campus of an Australian University that involves 7 business school faculty, the members explored the best curriculum for their course (Brown \& Peck, 2018). The CoP allowed faculty members to observe others' practices and learn from each other. In a qualitative study with 3 doctoral students and an alumni exploring identity development of the community members, Coffman, Putman, Adkisson, Kriner and Monaghan (2016) found that CoP helped the community address their professional identity struggles and define their professional identity as a scholar. This means transformation of a student identity to a researcher/professor identity in an academic field. In another study aiming to improve their students' mathemetics knowledge, four faculty members worked in a CoP and were able to contribute to their students' math development as well as their instutions' financial development and their personal and collective identities (Sack, Quander, Redl, \& Leveille, 2016). CoPs in most aforementioned examples provided unforseen benefits to the members and their organizations. This study aims to explore a CoP that was formed to identify and address the areas for improvement in a technology integration course at a Midwest university 
and improve preservice teachers' technology integration knowledge and skills through interventions of a CoP.

\section{Community of Practice}

Wenger (1998)'s community of practice (CoP) guided this research as the theoretical framework. CoP is defined as a collaboration space where stakeholders have a shared goal, reflect on their own experience (e.g. knowledge, practices), and develop interventions (e.g. resources, tools) to improve their practice (Wenger, McDermott, \& Snyder, 2002). The nature of the community, roles and responsibilities are all defined by the individual members of the community for active change and development of the practice. Barab, MaKinster, Moore, and Cunningham (2001) stressed that CoP approach supports a free knowledge sharing environment and collective understanding. However, this requires all its members to take active roles and contribute to all the phases of the development and evaluation of a practice. In CoP, members move from becoming individual thinkers to collaborative thinkers and evaluate the roles of the social and physical context in their practice (Barab, Barnett, \& Squire, 2002).

In the present research, the researcher and the instructors were the members of a group teaching the same technology integration course for pre-service teachers. The community members shared the same goal and aimed to improve the quality of the course in terms of content, instructional strategies and context. All the members' course sections and responsibilities were defined. Following the guidelines of the CoP approach, the instructors made a plan to conduct the community meetings. The professor served as a moderator to guide the discussions and keep track of the group tasks. In the meetings, the community reviewed the course content, identified areas for improvement, and designed interventions to improve the quality of the course. The researcher was a former instructor of the course; he values technology integration in K-12 education and believes that technology integration courses play an important role for teachers' effective technology integration. The researcher approached the community to explore their community interactions and their actions to improve the course implementation and outcomes.

\section{METHODOLOGY}

This research was designed and conducted considering the theoretical and practical suggestions of designbased research (DBR) methodology. Wang and Hannafin (2005) define DBR's important characteristics as "a systematic but flexible methodology aimed to improve educational practices through iterative analysis, design, development, and implementation, based on collaboration among researchers and practitioners in real-world settings, and leading to contextually-sensitive design principles and theories" (pg. 6). In DBR, real life context and colleagues are the main guide of the research process (Barab \& Squire, 2004). Similar to DBR, aforementioned characteristics are also at the center of CoP (Kilbride, Perry, Flatley, Turner, \& Meyer, 2011). Therefore, CoP and DBR methodology align well in terms of working within a community of practitioners to address real life problems and make suggestions for pre-service teachers' technology integration course design and revisions.

The purpose of this study is to explore a community of teacher educators aimed to identify and address the areas for improvement in a technology integration course at a Midwest university in the US. This study aims to answer the following research questions:

1. What are the areas for improvement in a technology integration course in a teacher education to better prepare pre-service teachers for effective technology integration in their future classroom?

2. What changes can be made to address areas for improvement in a technology integration course in a teacher education to better prepare pre-service teachers for effective technology integration in their future classroom?

3. How do teacher educators work in a community of practice to identify and address areas for improvement in a technology integration course in a teacher education to better prepare pre-service teachers for effective technology integration in their future classroom? 


\section{Research Setting and Participants}

The research was carried out at a large Midwest university in the US. The participants were the instructors who were teaching the technology integration course in the fall and spring semesters. One instructor was a professor teaching in an instructional technology department with over 10 years of teaching experience. All the other instructors were in the instructional department pursuing their doctorate degree. They had various teaching experience with different backgrounds (e.g. Computer Science Education, Social Studies, Math, English as a Second Language). Most of them were in their second or third year in the program. There were two new instructors teaching first time in higher education. The professor attended all the instructor meetings, organized and facilitated the discussions. Informed consent was obtained from all the participants. With the instructors' guidance, data was also collected from pre-service teachers taking the course in both semesters. It was a required course to complete the teacher education program. Most of the pre-service teachers enrolled this course in their first or second year. The main goal of the course was to prepare preservice teachers to effectively integrate technology into their future classroom. The course was offered for 15 weeks in three-hour blocks. There were eight instructors teaching eleven different sections in the fall and ten sections in the spring semesters. Even though the fall $(N=246)$ and spring $(N=216)$ semesters' pre-service teachers were different, they shared similar characteristics in terms of the number of the students in the sections, gender diversity, year in their program, age and subject areas. The pre-service teachers taking the course represented various subject areas, such as early education, elementary education, foreign language education, English language arts, secondary math, secondary life sciences, secondary physics, secondary social studies, teaching all learners, health education and visual arts. All the sections of the course followed the same syllabus that the instructors created at the beginning of the fall semester. The course included both teacher centered (e.g., instructor delivering lectures) and student centered (e.g., discussions groups, students creating products) instructional strategies. Based on the course syllabus, the pre-service teachers in this course completed the following assignments during the semester:

- Class-prep activities: Before each week's class, the pre-service teachers completed a short online activity to get familiar to the week's topic.

- In-class workouts: During the last hour of each class, the pre-service teachers used a technology tool and created a product that was related to each week's content.

- Case analysis: The pre-service teachers were required to complete two case analyses in teams. The cases included various problems that in-service teachers may experience in real life classroom settings.

- Teacher website: For one of the large final projects, the pre-service teachers envisioned their future classroom and created a fictitious teacher website.

- E-portfolio: The pre-service teachers created an online portfolio (e-portfolio) and shared their projects. The course followed the National Education Technology Standards for Teachers ("NETS-T") and the preservice teachers shared evidences of their work for each standard in the e-portfolio.

\section{Research Procedures}

The idea for this research was to improve the quality of this class in the instructors' own values, their definitions of the problems and possible solutions based on their observations and experiences. The researcher aims to identify and suggest principles to review, revise and improve technology integration courses in similar contexts with CoP approach as the guiding theory. In all the stages of this study, the researcher attended the instructor meetings and took observation field notes as a participant observer (Kluckhohn, 1940) to understand and interpret how the community worked together and made decisions in the research process. Participant observation is a data collection technique used when a researcher has longitudinal contact with the participants and aims to "generate theories and to develop understanding of specific organizational forms" (Bogdan, 1973, p. 303). The observations and the field notes helped the researcher to interpret the community interactions. 


\section{Week 8-9}

The instructors sent regular midterm course evaluations to preservice teachers

\section{Week 10}

The community discussed the preservice teachers' responses to learn their perceptions about the course (FGD1)

\section{Week 14}

The community discussed the questions and revized the questionnaire (FGD2)

\section{Week 15 \\ The questionnaire was distributed to the pre-service teachers at the end of the semester.}

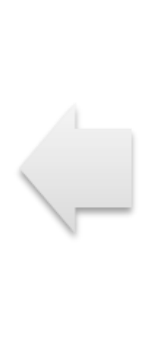

\section{Week 11-13}

FGD1 was verbatim transcribed, analyzed and a draft questionnaire was created to learn the pre-service teachers' challenges in course During the Winter Break
The community discussed the
questionnaire results and
developed interventions for the
spring semester course (FGD3).

Figure 1. Fall Semester Procedures

During all the stages of the study, the researcher also played a facilitator role and was guided by the instructors' ideas to conduct the study. The community decided to use two main data collection instruments (a) focus group discussions (FGD) and (b) pre/post questionnaires, and analyzed the data as a community. Below are the explanations of all the stages of the data collection and analysis procedures. Furthermore, Figure 1 and Figure 2 depict these procedures as a visual.

1. As part of the course, the instructors sent an online midterm course evaluation to their sections during week 8 or 9 classes of the fall semester and asked the pre-service teachers to report any difficulties they were experiencing in the course. The first FGD took place after these midterm evaluations were implemented, where the instructors shared their perceptions based on their observations and the results of the midterm evaluations. This FGD helped the community to identify the problems in the fall course (week 10).

2. After the first FGD, the researcher transcribed the meeting recording and analyzed the data using thematic analysis (Braun \& Clarke, 2006; Creswell \& Clark, 2017). The researcher did not use predefined codes. The data led the analysis process. The researcher coded, categorized and created the preliminary themes alone and created a draft questionnaire consisting of 20 questions. The community worked collaboratively, reviewed the questions and created the final version of the questionnaire with ten questions (week 14). The questionnaire was distributed at the end of the fall semester, week 15, to examine the pre-service teachers' perceptions regarding the problems identified by the community. The questionnaire was online, voluntary based and anonymous. While some instructors asked the pre-service 


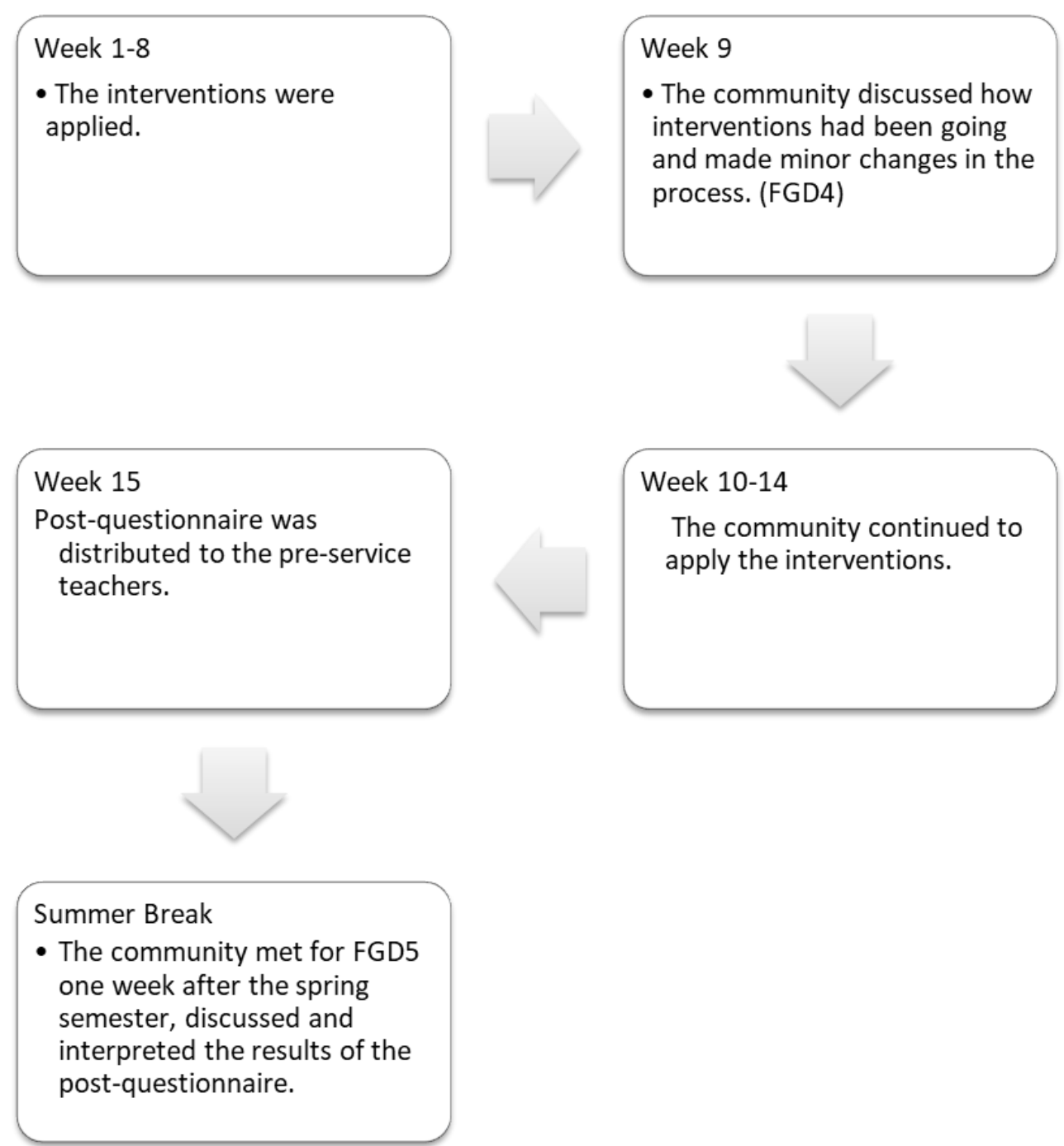

Figure 2. Spring Semester Procedures

teachers to complete the questionnaire during a class break, others preferred to send an online announcement and asked them to participate. Out of 246 pre-service teachers, 70 (28.45\%) pre-service teachers completed the questionnaire in the fall semester.

3. The third FGD helped interpret the pre-questionnaire results and suggest possible interventions as solutions for the spring semester. The questionnaire results were analyzed using descriptive statistics. The researcher calculated the mean scores for each item and the community discussed the results and interpreted what the results mean for their classroom context. Based on the results of this analysis, the community developed interventions to improve the quality of the course in all the sections.

4. The fourth FGD, during week 9 of the spring semester, helped to discuss how interventions had been going and to encourage the community to continue to apply the proposed changes.

5. The interventions were applied in the spring semester and the post-questionnaire was distributed during the final week of the spring semester. Out of 216 pre-service teachers, $63(29.16 \%)$ pre-service teachers completed the post-questionnaire. The results were analyzed using descriptive statistics to compare the fall and spring results for improvement. The community met for the fifth FGD one week after the spring semester, discussed and interpreted the results of the post-questionnaire. 


\section{Issues of Reliability and Validity}

In all the stages of this research, the data collection and analysis procedures were validated by the community members. The community members were all teacher educators teaching the technology integration course and had various sizes of experience in research. Therefore, they were able to actively contribute to the research process. The researcher audio recorded the FGD meetings and transcribed them verbatim. After each meeting, the community discussed and analyzed their own discussions to move further in the process. Furthermore, the pre-post questionnaire was created and interpreted as a community. Therefore, the community was active in all the stages of the research and contributed to the study not only to create valid and reliable research but also improve their own practice. Even though pre-post questionnaire was the primary data collection method in this study, the FGDs helped triangulate the data through teacher educators' contributions in the discussions.

\section{FINDINGS}

CoP framework and DBR methodology aligned well to identify and address the problems in the course. These were common goals essential for all the instructors in the community (Wenger et al., 2002). Furthermore, this study helped the researcher evaluate how the instructors with different backgrounds, perspectives and experience worked together as a community. Overall, the researcher noted that the members were responsible and concerned about the quality of their teaching practice and worked well. However, the researcher observed some challenges for applying the CoP framework with this group of the instructors in the FGDs. The community had international instructors teaching the course for the first time. The researcher observed and noted that these members were quiet and hesitant to present their comments during the discussions. Furthermore, one experienced member was sometimes dominant on her ideas and influenced the community decisions. For example, when the pre-survey results were discussed, one of the novice international instructors shared the pre-service teachers' concerns about "the assignments' high workload" (S). The experienced instructor neglected and commented about the concern: "I think the assignments are fine. [The pre-service teachers] are expected to spend six hours outside of the class time to complete the requirements" (K). Even though the issue was open to discussion in the community, the experienced instructor was insisted on her idea and interrupted the discussion. Therefore, that issue was not considered to be examined and addressed in the intervention list. Similar instances happened in the following meetings and the course director, a professor in the department, took active roles and asked for follow up ideas from other instructors, such as "what do you guys think about this problem?", "what is this problem about?". The course director as a facilitator encouraged all the members' participation. The course director's encouragements were successful and important for balancing the community dynamics. Overall, the community worked well and had success in identifying and addressing important issues in the fall semester. The next section demonstrates the problems identified in the first FGD. The following sections demonstrate the interventions as well as the outcomes of those interventions in the spring semester.

\section{Problems Identified in the Fall Semester}

\section{Lack of confidence}

Based on the fall questionnaire results, the instructors agreed on pre-service teachers' lack of confidence using technology in their future classroom. For example, one instructor reported: "They are still not very confident using technology and putting so much technology in their life" (B). Another instructor shared a similar concern: "I don't think they have confidence to teach with technology. My students share their hesitation to use smart board due to technical problems they may experience in front of classroom" (K).

\section{Poor connection between the assignments and the course content}

During the last hour of each class, the pre-service teachers complete an assignment called the in-class workouts. For this assignment, they used a technology tool and created a product that was related to the week's content. Some community members reported poor connection between the class preps, the in-class 
workouts and the weekly course content. The researcher observed the community members' confirmation of the problem. For example, referring to the class preps and the in-class workouts, one instructor shared the pre-service teachers' opinions: "We have too many small assignments. Couple of them [the pre-service teachers] indicated that [the assignments] are busy work and not meaningful work" (B). Another instructor highlighted: "One of my students, not in the midterm evaluation, but she talked to me in the class. So, everything we talked about in terms of the lesson, lecture part, she did not really feel that was relevant what she tries to produce in the in-class workouts" (J).

\section{Technology tools not useful for future classrooms}

The instructors emphasized the pre-service teachers' concerns regarding the inapplicability of technology tools they learned for their future classroom. For example, one instructor quoted her student (a pre-service teacher) from the midterm evaluations: "We are learning so many technologies that are changing rapidly. So, why we learn them now, by the time I graduate, those technologies will be changed" (R).

\section{Technology and subject incompatibility}

The instructors shared the pre-service teachers' negative attitudes regarding applicability of technology into their subject area. One instructor referred to her student's midterm response: "This one is an English teacher and she thinks that technology cannot be used in her English classroom" (R). Another teacher shared the same observation for biology pre-service teachers: "Biology teachers feel the same way. It seems we are focusing too much on the technology, not on the integration" (B).

\section{Limited time spent to complete the in-class workouts}

Some instructors shared the limited time they spend in the classroom to complete the in-class workouts. For example: "Some of my students shared that they are not be able to finish the in-class workouts in the class" (V). Another teacher shared same problem: "They always ask me whether I am going to give them more time on the [in-class workouts]. But then I always respond, well it depends on how other things go" (J).

\section{Pre-survey Results}

Based on the aforementioned discussions and his observations, the researcher created a questionnaire including 20 questions. The community reviewed the questions in the second FGD, revised and reduced the number of questions to 10 and used Likert-scale (1: Strongly disagree-2: Disagree-3: Neither agree nor disagree- 4: Agree- 5: Strongly Agree). The purpose of this questionnaire was to check if the concerns identified in the first FGD were common for all the sections of the course. The instructors distributed the survey in week 15 of the fall semester. The means are provided in Table 1 for all the pre-service teachers and also for each major responded to the questionnaire.

The results were interpreted together with the community in the $3^{\text {rd }}$ FGD and the issues below were highlighted:

1. Majority of the pre-service teachers reported that technology is not applicable to their subject areas.

2. Compared to the other majors, math secondary teachers reported lower confidence in selecting and using technology in their future classrooms.

3. A considerable number of the secondary teachers responded that the tools they learned will not be applicable to their future classroom.

4. A considerable number of pre-service teachers responded that they were not given enough time to explore technology tools in the class.

5. Majority of the pre-service teachers in all the sections responded that the class-preps did not prepare them to the weekly course content. The class-preps activities are short online assignments that the preservice teachers completed before each class to get familiar to the week's topic. 
Table 1. Pre-service Teachers Responses to the Areas for Improvement Identified in the Fall Semester

\begin{tabular}{|c|c|c|c|c|c|c|c|}
\hline $\begin{array}{l}\text { Please choose your major from the following } \\
\text { list }\end{array}$ & $\begin{array}{c}\text { Early } \\
\text { Education } \\
(n=7)\end{array}$ & $\begin{array}{c}\text { Elementary } \\
\text { Education } \\
(n=36)\end{array}$ & $\begin{array}{c}\text { Secondary } \\
\text { English \& } \\
\text { Language Arts } \\
(n=7)\end{array}$ & $\begin{array}{l}\text { Secondary } \\
\text { Math }(n=7)\end{array}$ & $\begin{array}{l}\text { Secondary } \\
\text { Science } \\
(n=3)\end{array}$ & $\begin{array}{l}\text { Secondary } \\
\text { Social } \\
\text { Studies } \\
(n=10)\end{array}$ & $\begin{array}{l}\text { TOTAL } \\
(\mathrm{n}=70)\end{array}$ \\
\hline $\begin{array}{l}\text { Technology is applicable in teaching my subject } \\
\text { area. }\end{array}$ & 3.86 & 4.06 & 3.71 & 3.29 & 4.50 & 4.50 & 4.05 \\
\hline $\begin{array}{l}\text { A lot of technology tools I learned in this class } \\
\text { will be useful in teaching my future classroom. }\end{array}$ & 3.71 & 4.11 & 4.00 & 3.29 & 3.50 & 3.90 & 3.97 \\
\hline $\begin{array}{l}\text { We spent sufficient time exploring each } \\
\text { technology tool in the class. }\end{array}$ & 4.00 & 3.83 & 4.00 & 3.57 & 4.00 & 3.70 & 3.79 \\
\hline $\begin{array}{l}\text { I feel confident in selecting appropriate } \\
\text { technology for my future classroom. }\end{array}$ & 4.00 & 3.81 & 4.14 & 3.71 & 4.50 & 4.00 & 3.9 \\
\hline $\begin{array}{l}\text { I feel confident in using technology in my } \\
\text { future classroom. }\end{array}$ & 4.00 & 3.89 & 4.00 & 3.71 & 4.50 & 4.30 & 3.95 \\
\hline $\begin{array}{l}\text { The class preps prepared me for the class every } \\
\text { week. }\end{array}$ & 3.43 & 3.31 & 2.57 & 2.71 & 3.00 & 3.10 & 3.04 \\
\hline $\begin{array}{l}\text { The in-class workouts helped me to reinforce } \\
\text { what we learned in the class. }\end{array}$ & 3.43 & 3.83 & 3.00 & 3.86 & 3.50 & 3.80 & 3.66 \\
\hline $\begin{array}{l}\text { I know how to solve various classroom } \\
\text { problems by using technology. }\end{array}$ & 3.86 & 3.83 & 4.29 & 3.57 & 4.00 & 3.40 & 3.83 \\
\hline $\begin{array}{l}\text { I know how to identify various classroom } \\
\text { problems. }\end{array}$ & 3.71 & 3.94 & 4.00 & 3.86 & 4.5 & 3.70 & 3.92 \\
\hline
\end{tabular}

Table 2. Problems Identified in the Fall and the Design Interventions in the Spring Semesters

\begin{tabular}{|c|c|}
\hline Problems Identified & Interventions Applied \\
\hline $\begin{array}{l}\text { - Secondary pre-service teachers had difficulty finding tools, } \\
\text { integrating technology into their subject areas and had } \\
\text { negative beliefs about technology. }\end{array}$ & $\begin{array}{l}\text { - Provide more secondary education specific examples and } \\
\text { practices in the spring sections. } \\
\text { - Provide support to the secondary education majors to find and } \\
\text { learn technology tools appropriate for the level. }\end{array}$ \\
\hline $\begin{array}{l}\text { - Pre-service teachers did not find the technology tools useful in } \\
\text { their future classroom. }\end{array}$ & $\begin{array}{l}\text { - Emphasize that the course is not a technology course and } \\
\text { encourage pre-service teachers to think about strategies and } \\
\text { tools useful in their future classroom. }\end{array}$ \\
\hline $\begin{array}{l}\text { - The pre-service teachers had difficulty in creating meaningful } \\
\text { relationship between the class preps, the in-class-workouts } \\
\text { and the course content. } \\
\text { - The class preps inadequately prepared the pre-service teachers } \\
\text { for the class every week. }\end{array}$ & $\begin{array}{l}\text { - Integrate the class-preps to each week's content and discuss } \\
\text { the results with the pre-service teachers. } \\
\text { - Revise the class-preps content and make them interesting and } \\
\text { relevant to the pre-service teachers. }\end{array}$ \\
\hline $\begin{array}{l}\text { - The in-class-workouts inadequately help the pre-service } \\
\text { teachers to reinforce what they learned in the class. } \\
\text { - The pre-service teachers do not have enough time to complete } \\
\text { the in-class-workouts during the class time }\end{array}$ & $\begin{array}{l}\text { - Revise the technology integration practices content and } \\
\text { connect it to the course content better. } \\
\text { - Change the assignment name "in-class-workout" to } \\
\text { "technology integration practice." }\end{array}$ \\
\hline
\end{tabular}

6. A considerable number of pre-service teachers responded that the in-class workouts did not help them reinforce what they learned in the class.

\section{Interventions for the spring semester}

Based on the community discussions and agreement between the members, the interventions listed in Table 2 were offered as solutions to improve the quality of the technology integration course in the spring semester.

\section{Post-survey Results}

After implementing the proposed changed in the spring semester, the instructors distributed the post survey to their new group of pre-service teachers in week 14 of the spring semester. The community conducted the last FGD at the end of the spring semester and discussed the post survey results (see Table $\mathbf{3}$ ). 
Table 3. Comparison of Fall and Spring Questionnaire Means (All Majors, Primary and Secondary Levels)

\begin{tabular}{|c|c|c|c|c|c|c|}
\hline \multirow{2}{*}{ Majors Grouped } & \multicolumn{2}{|c|}{ All Majors } & \multicolumn{2}{|c|}{ Primary } & \multicolumn{2}{|c|}{ Secondary } \\
\hline & Fall $(n=70)$ & $\begin{array}{l}\text { Spring } \\
(\mathrm{n}=53)\end{array}$ & Fall $(n=43)$ & $\begin{array}{l}\text { Spring } \\
(\mathrm{n}=27)\end{array}$ & Fall $(n=27)$ & $\begin{array}{l}\text { Spring } \\
(\mathrm{n}=26)\end{array}$ \\
\hline Technology is applicable in teaching my subject area & 4.01 & 4.30 & 4.02 & 4.12 & 4.00 & 4.48 \\
\hline $\begin{array}{l}\text { A lot of technology tools I learned in this class will be useful } \\
\text { in teaching my future classroom }\end{array}$ & 3.94 & 4.00 & 4.05 & 3.84 & 3.78 & 4.15 \\
\hline $\begin{array}{l}\text { We spent sufficient time exploring each technology tool in } \\
\text { the class }\end{array}$ & 3.83 & 3.96 & 3.86 & 3.92 & 3.78 & 3.96 \\
\hline $\begin{array}{l}\text { I feel confident in selecting appropriate technology for my } \\
\text { future classroom }\end{array}$ & 3.91 & 3.94 & 3.84 & 3.76 & 4.04 & 4.11 \\
\hline I feel confident in using technology in my future classroom & 3.99 & 4.17 & 3.90 & 4.00 & 4.11 & 4.30 \\
\hline The class preps did prepare me for the class every week & 3.13 & 4.08 & 3.32 & 4.08 & 2.81 & 4.07 \\
\hline $\begin{array}{l}\text { The technology integration practices helped me to reinforce } \\
\text { what we learned in the class }\end{array}$ & 3.70 & 3.98 & 3.76 & 4.00 & 3.59 & 3.93 \\
\hline $\begin{array}{l}\text { I know how to solve various classroom problems by using } \\
\text { technology }\end{array}$ & 3.93 & 3.91 & 3.93 & 3.80 & 3.93 & 3.96 \\
\hline I know how to identify various classroom problems & 3.80 & 3.89 & 3.81 & 3.92 & 3.78 & 3.85 \\
\hline
\end{tabular}

In addition to comparing the overall mean scores for all of the participants, the community decided to make the comparison based on education stages as primary and secondary. This decision was due to the interventions made in the spring semester, which mainly aimed to make changes in aforementioned stages but not on specific subject areas.

One of the interventions in the spring semester aimed to provide more secondary specific examples and practices and provide more support to the secondary education majors. This attention changed secondary pre-service teachers' beliefs in a positive way and improved their confidence to select and use technology appropriately in their future classroom. However, the beliefs and confidence scores reduced for the primary stage pre-service teachers in the spring semester. The community discussed this new problem and shared the reason as focusing mostly on the secondary level pre-service teachers. For example, one instructor shared:

This semester I focused on more secondary education, provided more examples. I really provided a lot of examples focusing on secondary that might be a reason. I feel like, yes, maybe sometimes ignored, not ignored like paid less attention, spent less time with the elementary folks (S).

The instructors shared that it requires more preparation to teach in sections where there are diverse subject area pre-service teachers. For example, $\mathrm{L}$ shared:

I know $[R]$ had a much diverse mixture. There has to be a way for us to make us talk about strategies to be able to give examples all of those areas, whether it is through individualized feedback in the class preps or you walking around any saying: "I really think you should try this program." So, I think that we need to be prepared for those different areas.

In order to create a supportive and positive environment in the future semesters, the community decided to identify and consider pre-service teachers' subject areas at the beginning of the semester, plan the technology tools available for different sections of the course. The instructors decided to create a repository of technology resources and examples, share them via the course website and allow pre-service teachers to find resources available in different subject areas. One teacher commented: "Whenever an instructor needs to demonstrate a subject specific tool or a pre-service teacher trying to find a tool for his/her major, s/he could refer to the repository" (K).

After the interventions in the spring semester, the biggest positive shift was on the pre-service teachers' conceptions about the class prep assignments. The pre-service teachers were able to see the connection between the class-preps and the weekly course content better. The community shared their satisfaction of 
the results in the meeting: "It seems like we overcame the [class preps] issue. We need to continue doing what we have done this semester" (L). In another intervention, the community offered to change the name "in-class workout" to "technology integration practice." As an effective change, the community decided to continue to use the new name "technology integration practice" to eliminate the pre-service teachers' complains about the limited time left for "the in-classworkout" assignments.

\section{DISCUSSION}

The present study explored a community of teacher educators' participation in a CoP to identify and address the problems in a technology integration course. The CoP focused on the instructors' reflections of their experience and the interventions to improve their practice (Wenger et al., 2002). The community decided the data collection procedures, used FGDs and questionnaires to identify and address the problems. During these interactions, the researcher observed and examined the community dynamics as an external member, investigated how the instructors worked as a community, what influenced their decision-making processes, and aimed to make suggestions for similar CoPs in teacher education programs.

The findings suggest that technology integration courses provide the foundation for technology and pedagogy knowledge (Mouza, Karchmer-Klein, Nandakumar, Ozden, \& Hu, 2014). However, they offer limited time to practice technology integration and sustain new knowledge and skills and positive beliefs. In order to address the challenges of the one course format, different strategies were offered. For example, in a recent study, faculty in teacher educations are expected to infuse technology in all the method courses, and "create curriculum and provide technology rich experiences to help students develop their content, pedagogy and technology knowledge" through methods courses and student teaching experiences (Foulger, Wetzel, \& Buss, 2019, p. 2). This approach expressed the need to think the program level of technology integration rather than the course level (Wetzel, Foulger, \& Williams, 2008). Mouza et al. (2014) investigated and compared the impacts of the one course model with the technology-infused approach and found that one educational technology course is vital to improve pre-service teachers' technology knowledge. Furthermore, teacher educators who practiced technology-infused approach were limited in the application of technological pedagogical knowledge and focused more on the pedagogical knowledge level in their classes. The findings of the Mouza et al. (2014) study suggests that even though integrated approach provide pedagogical benefits, due to teacher educators' limited knowledge and experience in technology integration, educational technology course is essential to improve "preservice teachers' ability to combine content, pedagogy and technology in the design and implementation of technology-integrated lessons" (p. 219). Therefore, it is important to constantly review and revise educational technology course content and strategies to meet the students' ever changing needs (Ottenbreit-Leftwich, Glazewski, \& Newby, 2010).

\section{Beliefs}

Pre-service teachers' beliefs to use technology in their future classrooms is an important condition for effective technology integration (Ertmer, Ottenbreit-Leftwich, Sadik, Sendurur, \& Sendurur, 2012; Farjon, Smits, \& Voogt, 2019; Tondeur et al., 2017). In the questionnaire results, the community recognized that preservice teachers did not value technology integration and hesitant to use technology in their subject area teaching. In order to address this concern, the findings suggest that teacher educators need to know preservice teachers in detail (e.g. subject area, technology preconceptions, beliefs regarding technology) and guide them to build and sustain positive beliefs regarding technology integration. Furthermore, they need to provide examples and activities relevant to pre-service teachers' subject areas (Angeli, 2005; Trainin, Friedrich, \& Deng, 2018) and allow them to make connections between technology, pedagogy and content (Tondeur, Pareja Roblin, Van Braak, Voogt, \& Prestridge, 2017). This condition was also stressed as an important condition in Technological, Pedagogical, Content Knowledge Framework (TPACK) (Koehler \& Mishra, 2009). 


\section{Assignments}

Another major area for improvement was assignments in the fall semester. The community decided to make design changes and integrate the class-prep assignments' content to the in-class discussions and activities. Furthermore, they aimed to connect all the class-preps and the technology integration practices to the course content and the pre-service teachers' interests. Creating meaningful assignments for students is an important condition of a successful learning experience in any learning context (Morrison, Ross, Morrison, \& Kalman, 2019). In a study with 200 first year computer science students in an introduction to programming class, Layman, Williams, Williams, and Slaten (2007) asserted that making an assignment meaningful does not need big changes on the context. Adding or changing small details can make assignments more meaningful for the students (Layman et al., 2007). This suggestion is aligned with the findings of the current research study. Changing the name of the in-class workouts to technology integration practice made an impact on the students' perceptions about their learning experience. Courses in technology integration need to offer assignments that are meaningful and impactful for pre-service teachers' learning needs (Tondeur et al., 2017).

\section{CoP in Teacher Education}

CoP approach was implemented in this research to identify and address the issues in a technology integration course for pre-service teachers. CoP is a setting that share common goals, activities, resources and limitations in a professional culture (Kuhn, 2002). The problems identified in the post findings suggest the ongoing cycles of reviews and revisions of technology integration courses as a community. Based on the findings and the researcher's observations as an outsider, CoP is suggested as a helpful approach in similar contexts. However, some factors limit the community interactions and teamwork. As the previous literature suggested, successful CoP depends on defining strategic objectives for and active participation of all the community members (Barab et al., 2002). Wenger et al. (2002) defines this as joint enterprise that binds the members together. Clear and meaningful objectives motivate members and give them responsibility to improve their practice.

However, even with strategic objectives that were meaningful for all the participants' professional practice, individual members of the community may influence the quality of participation in CoP environments. Thus, the community becomes restricted. The findings suggest considering a teacher educator community's social configurations as a critical condition for the quality of the CoP efforts. New or novice members may shy away from the discussions due to fear of criticism or providing false information to the community (Ardichvili, Page, \& Wentling, 2003). Therefore, CoP environments in teacher education need a moderator to encourage more discussions and collaboration between the members (Probst \& Borzillo, 2008). This moderator needs to be an experienced senior insider of the community who can help the community to reach the full potential by considering the weaknesses, strengths and the relations between the members (Baker \& Beames, 2016).

\section{CONCLUSION}

In this DBR study, problems in a technology integration course were identified, analyzed, interpreted and addressed in a community of teacher educators. In the current conditions of teacher education institutions, recent studies stressed the importance educational technology courses for preparing pre-service teachers for technology integration. Therefore, reviewing and revising technology integration coursework emerged as important ongoing needs. However, technology integration courses have short-term impact on pre-service teachers' technology integration knowledge, beliefs, confidence and practice. After taking one course, preservice teachers need to continue to see successful examples of technology integration in other teacher education courses and use technology in their teaching practices.

This study has some limitations. For instance, the pre-service teachers in the fall and spring semesters were different. Even though they share similar characteristics, comparing different groups can be a limitation. Furthermore, this study was conducted in one institution and the findings cannot be generalized to other higher education contexts. However, there is potential benefits for transferability of findings to similar 
contexts. The researcher was a member of the same community in the previous years. Therefore, his relationships with the community members and previous experience might influence the interpretation of the findings.

This study has important implications for practice and research. CoP approach was successful to examine and improve the quality of the technology integration course and this study provides suggestions for teacher educators to apply a similar CoP approach to improve their courses. However, community members need to consider the community dynamics and identify and share roles for community success. In terms of research, using DBR in CoP was an innovative approach to create knowledge sharing communities in teacher education in technology integration. However, future research studies are needed to compare and validate the findings with more data. It would be helpful to locate problems in different contexts and identify the overarching problems in pre-service teacher technology integration preparation.

\section{Ethical Statement}

The study has been approved by the institutional research ethics committee and has been performed in accordance with the ethical standards as laid down in the 1964 Declaration of Helsinki and its later amendments or comparable ethical standards.

\section{REFERENCES}

Angeli, C. (2005). Transforming a teacher education method course through technology: Effects on preservice teachers' technology competency. Computers \& Education, 45(4), 383-398. https://doi.org/10.1016/j.compedu.2004.06.002

Ardichvili, A., Page, V., \& Wentling, T. (2003). Motivation and barriers to participation in virtual knowledgesharing communities of practice. Journal of Knowledge Management, 7(1), 64-77. https://doi.org/10.1108/13673270310463626

Baker, A., \& Beames, S. (2016). Good CoP: What makes a community of practice successful? Journal of Learning Design, 9(1), 72-79. https://doi.org/10.5204/jld.v9i1.234

Barab, S. A., \& Squire, K. (2004). Design-based research: Putting a stake in the ground. The Journal of the Learning Sciences, 13(1), 1-14. https://doi.org/10.1207/s15327809jls1301_1

Barab, S. A., Barnett, M., \& Squire, K. (2002). Developing an empirical account of a community of practice: Characterizing the essential tensions. The Journal of the Learning Sciences, 11(4), 489-542. https://doi.org/10.1207/S15327809JLS1104_3

Barab, S. A., MaKinster, J. G., Moore, J. A., \& Cunningham, D. J. (2001). Designing and building an on-line community: The struggle to support sociability in the inquiry learning forum. Educational Technology Research and Development, 49(4), 71-96. https://doi.org/10.1007/BF02504948

Baturay, M. H., Gökçearslan, Ş., \& Ke, F. (2017). The relationship among pre-service teachers' computer competence, attitude towards computer-assisted education, and intention of technology acceptance. International Journal of Technology Enhanced Learning, 9(1), 1-13. https://doi.org/10.1504/IJTEL.2017.084084

Bogdan, R. (1973). Participant observation. Peabody Journal of Education, 50(4), 302-308. https://doi.org/10.1080/01619567309537925

Braun, V., \& Clarke, V. (2006). Using thematic analysis in psychology. Qualitative Research in Psychology, 3(2), 77-101. https://doi.org/10.1191/1478088706qp063oa

Brown, J. S., \& Duguid, P. (1991). Organizational learning and communities of practice: Toward a unified view of working, learning, and innovation. Organization Science, 2(1), 40-57. Retrieved from www.jstor.org/stable/2634938 
Brown, M., \& Peck, C. (2018). Expanding the landscape: Developing knowledgeability through communities of practice. International Journal for Academic Development, 23(3), 232-243. https://doi.org/10.1080/1360144X.2018.1473252

Chai, C. S., Koh, J. H. L., \& Tsai, C. C. (2010). Facilitating preservice teachers' development of technological, pedagogical, and content knowledge (TPACK). Educational Technology \& Society, 13(4), 63-73. Retrieved from https://eric.ed.gov/?id=EJ909933

Coffman, K., Putman, P., Adkisson, A., Kriner, B., \& Monaghan, C. (2016). Waiting for the expert to arrive: Using a community of practice to develop the scholarly identity of doctoral students. International Journal of Teaching and Learning in Higher Education, 28(1), 30-37. Retrieved from https://files.eric.ed.gov/fulltext/EJ1106332.pdf

Creswell, J. W., \& Clark, V. L. P. (2017). Designing and conducting mixed methods research: Sage Publications.

Cullen, T. A., \& Greene, B. A. (2011). Preservice teachers' beliefs, attitudes, and motivation about technology integration. Journal of Educational Computing Research, 45(1), 29-47. https://doi.org/10.2190/EC.45.1.b

Dufour, R., \& Eaker, R. (1998). Professional learning communities at work: Best practices for enhancing student achievement. Alexandria, VA: Association for Supervision and Curriculum Development. Retrieved from https://eric.ed.gov/?id=ED426472

Elwood, K., \& Savenye, W. (2015). Current tensions: A review of technology integration models utilized by preservice teacher educator programs. Paper presented at the Society for Information Technology \& Teacher Education International Conference, Chesapeake, VA.

Ertmer, P. A., Ottenbreit-Leftwich, A. T., Sadik, O., Sendurur, E., \& Sendurur, P. (2012). Teacher beliefs and technology integration practices: A critical relationship. Computers \& Education, 59(2), 423-435. https://doi.org/10.1016/j.compedu.2012.02.001

Farjon, D., Smits, A., \& Voogt, J. (2019). Technology integration of pre-service teachers explained by attitudes and beliefs, competency, access, and experience. Computers \& Education, 130, 81-93. https://doi.org/10.1016/j.compedu.2018.11.010

Foulger, T. S., Wetzel, K., \& Buss, R. R. (2019). Moving toward a technology infusion approach: Considerations for teacher preparation programs. Journal of Digital Learning in Teacher Education, 1-13. https://doi.org/10.1080/21532974.2019.1568325

Gehrke, S., \& Kezar, A. (2017). The roles of STEM faculty communities of practice in institutional and departmental reform in higher education. American Educational Research Journal, 54(5), 803-833. https://doi.org/10.3102/0002831217706736

Gronseth, S., Brush, T., Ottenbreit-Leftwich, A., T., Strycker, J., Abaci, S., Easterling, W., . . Leusen, P. V. (2010). Equipping the next generation of teachers: Technology preparation and practice. Journal of Digital Learning in Teacher Education, 27(1), 30-36. https://doi.org/10.1080/21532974.2010.10784654

Harris, J., Mishra, P., \& Koehler, M. (2009). Teachers' technological pedagogical content knowledge and learning activity types: Curriculum-based technology integration reframed. Journal of Research on Technology in Education, 41(4), 393-416. https://doi.org/10.1080/15391523.2009.10782536

Hord, S. M. (2004). Professional learning communities: An overview. In Learning together, leading together: Changing schools through professional learning communities (Shirley Hord, Ed.). New York: Teachers College Press, 5-14. 
Jakovljevic, M., \& Da Veiga, A. (2020). An integrated academic community of practice model (ACoPM). Innovations in Education and Teaching International, 57(3), 339-351. https://doi.org/10.1080/14703297.2019.1623061

Kilbride, C., Perry, L., Flatley, M., Turner, E., \& Meyer, J. (2011). Developing theory and practice: Creation of a community of practice through action research produced excellence in stroke care. Journal of Interprofessional Care, 25(2), 91-97. https://doi.org/10.3109/13561820.2010.483024

Kluckhohn, F. R. (1940). The participant-observer technique in small communities. American Journal of Sociology, 46(3), 331-343. https://doi.org/10.1086/218650

Koehler, M., \& Mishra, P. (2009). What is technological pedagogical content knowledge (TPACK)? Contemporary Issues in Technology and Teacher Education, 9(1), 60-70.

Kuhn, T. (2002). Negotiating boundaries between scholars and practitioners: Knowledge, networks, and communities of practice. Management Communication Quarterly, 16(1), 106-112. https://doi.org/10.1177/0893318902161008

Layman, L., Williams, L., Williams, L., \& Slaten, K. (2007). Note to self: make assignments meaningful. ACM SIGCSE Bulletin, 39(1), 459-463. https://doi.org/10.1145/1227504.1227466

Morrison, G. R., Ross, S. J., Morrison, J. R., \& Kalman, H. K. (2019). Designing effective instruction. Hoboken, New Jersey: Wiley.

Mouza, C., Karchmer-Klein, R., Nandakumar, R., Ozden, S. Y., \& Hu, L. (2014). Investigating the impact of an integrated approach to the development of preservice teachers' technological pedagogical content knowledge (TPACK). Computers \& Education, 71, 206-221. https://doi.org/10.1016/j.compedu.2013.09.020

Ottenbreit-Leftwich, A. T., Glazewski, K., \& Newby, T. (2010). Preservice technology integration course revision: A conceptual guide. Journal of Technology and Teacher Education, 18(1), 5-33. Retrieved from https://eric.ed.gov/?id=EJ896287

Probst, G., \& Borzillo, S. (2008). Why communities of practice succeed and why they fail. European Management Journal, 26(5), 335-347. https://doi.org/10.1016/j.emj.2008.05.003

Sack, J., Quander, J., Redl, T., \& Leveille, N. (2016). The community of practice among mathematics and mathematics education faculty members at an urban minority serving institution in the US. Innovative Higher Education, 41(2), 167-182. https://doi.org/10.1007/s10755-015-9340-9

Sadaf, A., Newby, T. J., \& Ertmer, P. A. (2016). An investigation of the factors that influence preservice teachers' intentions and integration of Web 2.0 tools. Educational Technology Research and Development, 64(1), 37-64. https://doi.org/10.1007/s11423-015-9410-9

Sosa, T. (2009). The missing piece of your technology integration course. TechTrends, 53(2), 55-58. https://doi.org/10.1007/s11528-009-0270-1

Stoll, L., Bolam, R., McMahon, A., Wallace, M., \& Thomas, S. (2006). Professional learning communities: A review of the literature. Journal of Educational Change, 7(4), 221-258. https://doi.org/10.1007/s10833-006-0001-8

Tondeur, J., Pareja Roblin, N., Van Braak, J., Voogt, J., \& Prestridge, S. (2017). Preparing beginning teachers for technology integration in education: Ready for take-off? Technology, Pedagogy and Education, 26(2), 157-177. https://doi.org/10.1080/1475939X.2016.1193556 
Tondeur, J., Van Braak, J., Ertmer, P. A., \& Ottenbreit-Leftwich, A. T. (2017). Understanding the relationship between teachers' pedagogical beliefs and technology use in education: A systematic review of qualitative evidence. Educational Technology Research and Development, 65(3), 555-575. https://doi.org/10.1007/s11423-016-9481-2

Trainin, G., Friedrich, L., \& Deng, Q. (2018). The impact of a teacher education program redesign on technology integration in elementary preservice teachers. Contemporary Issues in Technology and Teacher Education, 18(4). Retrieved from https://eric.ed.gov/?id=EJ1198782

Wang, F., \& Hannafin, M. J. (2005). Design-based research and technology-enhanced learning environments. Educational Technology Research and Development, 53(4), 5-23. https://doi.org/10.1007/BF02504682

Wang, T. (2016). School leadership and professional learning community: Case study of two senior high schools in Northeast China. Asia Pacific Journal of Education, 36(2), 202-216. https://doi.org/10.1080/02188791.2016.1148849

Wenger, E. (1998). Communities of practice: Learning, meaning, and identity. New York City: Cambridge University Press. https://doi.org/10.1017/СBO9780511803932

Wenger, E., McDermott, R. A., \& Snyder, W. (2002). Cultivating communities of practice: A guide to managing knowledge. Boston, MA: Harvard Business Press.

Wetzel, K., Foulger, T. S., \& Williams, M. K. (2008). The evolution of the required educational technology course. Journal of Computing in Teacher Education, 25(2), 67-71. https://doi.org/10.1080/10402454.2008.10784611

Willis, J., \& Cifuentes, L. (2005). Training teachers to integrate technology into the classroom curriculum: Online versus face-to-face course delivery. Journal of Technology and Teacher Education, 13(1), 43-63. Retrieved from https://www.learntechlib.org/primary/p/4404/

Zipke, M. (2018). Preparing teachers to teach with technology: Examining the effectiveness of a course in educational technology. The New Educator, 14(4), 342-362. https://doi.org/10.1080/1547688X.2017.1401191

Correspondence: Olgun Sadik, Indiana University, USA and Inonu University, Turkey. E-mail: olgunsadik@gmail.com 